\title{
Effects of Salt Stress on Plant Growth, Antioxidant Capacity, Glandular Trichome Density, and Volatile Exudates of Schizonepeta tenuifolia Briq.
}

\author{
Ying Zhou, Nanyu Tang, Lijin Huang, Yongjuan Zhao, Xiaoqing Tang * and Kangcai Wang * \\ College of Horticulture, Nanjing Agricultural University, Nanjing 210095, China; 2016104130@njau.edu.cn (Y.Z.); \\ 14415225@njau.edu.cn (N.T.); 14415226@njau.edu.cn (L.H.); 14415222@njau.edu.cn (Y.Z.) \\ * Correspondence: xqtang@njau.edu.cn (X.T.); wangkc@njau.edu.cn (K.W.); Tel./Fax: +86-25-8439-5150 (X.T.)
}

Received: 6 December 2017; Accepted: 11 January 2018; Published: 15 January 2018

\begin{abstract}
Salinity is a major abiotic factor affecting plant growth and secondary metabolism. However, no information is available about its effects on Schizonepeta tenuifolia Briq., a traditional Chinese herb. Here, we investigated the changes of plant growth, antioxidant capacity, glandular trichome density, and volatile exudates of $S$. tenuifolia exposed to salt stress $(0,25,50,75,100 \mathrm{mM} \mathrm{NaCl})$. Results showed that its dry biomass was reduced by salt treatments except $25 \mathrm{mM} \mathrm{NaCl}$. Contents of antioxidants, including phenolics and flavonoids, increased at low $(25 \mathrm{mM})$ or moderate $(50 \mathrm{mM})$ levels, but declined at severe $(75$ and $100 \mathrm{mM})$ levels. On leaf surfaces, big peltate and small capitate glandular trichomes (GTs) were found. Salt treatments, especially at moderate and severe concentrations, enhanced the density of total GTs on both leaf sides. The most abundant compound in GT volatile exudates was pulegone. Under salinity, relative contents of this component and other monoterpenes decreased significantly; biosynthesis and accumulation of esters were enhanced, particularly sulfurous acid,2-ethylhexyl hexyl ester, which became the second major compound as salinity increased. In conclusion, salt stress significantly influenced the growth and secondary metabolism of S. tenuifolia, enabling us to study the changes of its pharmacological activities.
\end{abstract}

Keywords: salt stress; Schizonepeta tenuifolia Briq.; growth; antioxidant activities; glandular trichome density; volatile exudates

\section{Introduction}

Schizonepeta tenuifolia Briq. (Jingjie in Chinese) is an annual plant belonging to the Lamiaceae family. Now, it is cultivated for medicinal and culinary purposes, namely it is used as an ingredient in herbal medicines, beneficial teas, food recipes, sauces, and beverages. In China, Japan, and Korea, dried aerial parts of $S$. tenuifolia have long been popularly used as a traditional medicinal herb to treat headaches, colds, fevers, sore throats, allergic dermatitis, eczema, and psoriasis $[1,2]$. Modern pharmacological studies have shown that its methanolic or aqueous extracts have antioxidant, anti-inflammatory, antipruritic, and antiviral activities [3-5]. Like many plants in the Lamiaceae family, this medicinal and aromatic plant also produces essential oil (EO), which is considered the major material basis of its biological effects, and exhibits anti-inflammatory [6] and insecticidal $[7,8]$ activity. Main components in EO distilled from S. tenuifolia aerial parts are monoterpenes including pulegone, d-limonene and menthone [1]. Pulegone, with a pleasant and refreshing odor, is commercially used in flavoring agents, perfumery, aromatherapy, and diverse pharmaceuticals [9]. In the Chinese Pharmacopoeia [10], pulegone was selected as the marker compound for quality control of schizonepetae herba. D-limonene, one of the most common terpenes in nature, is a principal component in several citrus oils (orange, lemon, grapefruit, mandarin, and lime). It is listed in the Code of Federal Regulation of the United States of America (USA) as generally recognized as safe for 
a flavor and fragrance additive in foods, perfumes, beverages, soaps, and chewing gum. Clinically, d-limonene is used for dissolving cholesterol-containing gallstones and relief of heartburn [11]. As for menthone, it is used in household products, components of artificial volatile oils, and tooth-brushing powder [12]. The EO is medicinally important since it is one of the raw materials of many Chinese Traditional Patent Medicines [13]. In the plant kingdom, there are specialized tissues and cell types responsible for synthesizing and accumulating secondary metabolites, such as secretory cavities, resin ducts, laticifers, glandular trichomes (GTs), and gum ducts [14,15]. While in the Lamiaceae species, the glandular trichome (GT) of the epidermal structure is the site that serves for the biosynthesis, secretion, and accumulation of EO [16]. Due to its location on the plant surface and the hydrophobic property of metabolites synthesized by GT, GT exudates can be recovered by simple organic solvent washes [17]. This accessibility has, therefore, made it possible for us to study the metabolic profiling of GTs, in addition to extracting essential oil by steam distillation.

Salinity is one of the major abiotic factors reducing global crop yield; it affects nearly $20 \%$ of the cultivated lands around the world and about $50 \%$ of all irrigated lands $[18,19]$. In China, there are about 34.6 million hectares of salinized lands. Among the major and vital groups of crops, the medicinal plants, which exert an important role in human disease prevention and treatment [20], are also being threatened by this constraint. It is well established that secondary metabolites in medicinal plants are involved in the treatment of human diseases and health disorders [21]. However, their accumulation is strongly dependent on growing conditions [22]. Among the secondary metabolites, polyphenolic compounds with strong antioxidant activities are abundant in the Lamiaceae plants [23]. Under salinity and other biotic/abiotic stresses, their synthesis and accumulation are generally vitalized [24]. Thus, it has been suggested that plants stressed by salinity might have the potential to be sources of polyphenols [25].

S. tenuifolia is able to grow in most regions of China but is mainly cultivated commercially in northeastern and northern China. In the past few years, these areas have been confronted with soil secondary salinization due to inappropriate fertilizer and irrigation management. Moreover, cultivation of S. tenuifolia is also being conducted on improved coastal saline soils. Thus, research concerning the impacts caused by salinity on the growth and secondary metabolism of S. tenuifolia is needed. In this study, we aimed to investigate the changes of plant growth and antioxidant capacity of S. tenuifolia in response to salt stress. Furthermore, GTs are specialized hairs found on plant aerial parts and are responsible for large portions of the plant's secondary chemistry [26]. The occurrence of GTs in S. tenuifolia has compelled us to evaluate how salt stress affected their density and composition of volatile exudates. This study will deepen our understanding of aspects of secondary metabolic changes induced by salt stress in the traditional Chinese herb, S. tenuifolia.

\section{Results}

\subsection{Plant Growth}

In Figure 1A, a substantial and obvious decrease in S. tenuifolia plant height was observed at 25, 50,75 , and $100 \mathrm{mM} \mathrm{NaCl}$ by $15.41 \%, 20.43 \%, 29.99 \%$, and $36.13 \%$, respectively, compared with the control. Total dry weight of plants exhibited a slight rise at $25 \mathrm{mM} \mathrm{NaCl}$ but reduced significantly by $14.44 \%, 18.33 \%$, and $31.6 \%$ at 50,75 , and $100 \mathrm{mM} \mathrm{NaCl}$, respectively, compared with the control. 

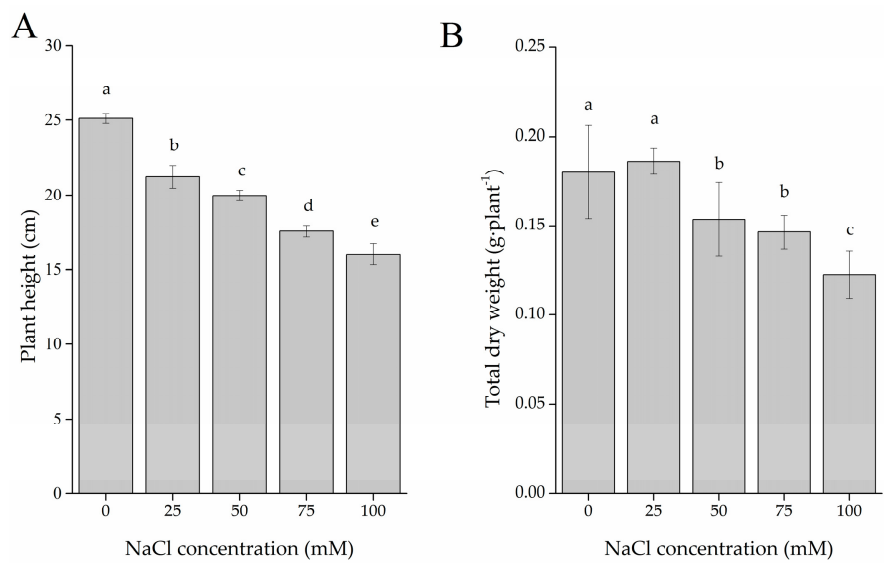

Figure 1. Plant growth of S. tenuifolia influenced by salt stress. (A) Plant height and (B) total dry weight of plants treated by five different $\mathrm{NaCl}$ concentrations. Data are expressed as the mean $\pm \mathrm{SD}$. Bars with different letters are significantly different at $p<0.05(n=10)$.

\subsection{Total Phenolic and Flavonoid Content (TPC and TFC)}

As shown in Table 1, the total phenolic content (TPC) of S. tenuifolia leaf was measured as $13.24 \mathrm{mg}$ GAE/g DW (mg of gallic acid equivalents on a basis of dry weight) in the control. At $25 \mathrm{mM} \mathrm{NaCl}$, a significant increase in TPC was observed, which was 1.4 times higher than that of the control. However, higher concentrations of salinity caused a diminution in TPC. The TPC value at 50 and $75 \mathrm{mM} \mathrm{NaCl}$ was 14.56 and $12.37 \mathrm{mg}$ GAE/g DW, respectively, which was deemed to be at the same level as the control. At $100 \mathrm{mM} \mathrm{NaCl}$, the obvious decrease was of about $44 \%$ as compared to the control plants. Similar but not the same, the accumulation of flavonoids was enhanced by low $(25 \mathrm{mM} \mathrm{NaCl})$ to moderate levels $(50 \mathrm{mM} \mathrm{NaCl})$ of salinity but was inhibited by severe levels $(75 \mathrm{mM}, 100 \mathrm{mM} \mathrm{NaCl})$.

Table 1. Total phenolic and flavonoid content and antioxidant activity of S. tenuifolia leaves influenced by salt stress.

\begin{tabular}{ccccc}
\hline $\begin{array}{c}\text { NaCl Concentration } \\
(\mathbf{m M})\end{array}$ & $\begin{array}{c}\text { TPC }(\mathbf{m g} \\
\text { GAE/g DW) }\end{array}$ & $\begin{array}{c}\text { TFC }(\mathbf{m g} \\
\text { Rutin/g DW) }\end{array}$ & $\begin{array}{c}\text { DPPH (\% Antioxidant } \\
\text { Capacity) }\end{array}$ & $\begin{array}{c}\text { ABTS }(\mu \mathrm{mol} \\
\text { TEAC/g DW) }\end{array}$ \\
\hline 0 & $13.24 \pm 1.90^{\mathrm{bc}}$ & $31.43 \pm 2.64^{\mathrm{b}}$ & $40.17 \pm 2.41^{\mathrm{c}}$ & $54.69 \pm 3.26^{\mathrm{b}}$ \\
25 & $18.54 \pm 0.66^{\mathrm{a}}$ & $38.99 \pm 0.80^{\mathrm{a}}$ & $62.14 \pm 2.67^{\mathrm{a}}$ & $75.40 \pm 5.54^{\mathrm{a}}$ \\
50 & $14.56 \pm 1.32^{\mathrm{b}}$ & $36.27 \pm 1.01^{\mathrm{a}}$ & $44.79 \pm 2.31^{\mathrm{b}}$ & $57.44 \pm 6.73^{\mathrm{b}}$ \\
75 & $12.37 \pm 0.51^{\mathrm{c}}$ & $24.26 \pm 1.33^{\mathrm{c}}$ & $29.56 \pm 1.59^{\mathrm{d}}$ & $44.83 \pm 1.61^{\mathrm{c}}$ \\
100 & $7.40 \pm 0.32^{\mathrm{d}}$ & $17.18 \pm 1.72^{\mathrm{d}}$ & $18.30 \pm 0.70^{\mathrm{e}}$ & $30.69 \pm 2.21^{\mathrm{d}}$ \\
\hline
\end{tabular}

TPC, total phenolic content; TFC, total flavonoid content; mg GAE/g DW, mg of gallic acid equivalents on a basis of dry weight; DPPH (2,2-diphenyl-1-picrylhydrazyl); ABTS (2,2'-azinobis-(3-ethylbenzothiazoline-6-sulfonic acid)); $\mu \mathrm{mol}$ TEAC/g DW, $\mu \mathrm{mol}$ of trolox equivalent antioxidant capacity on a basis of dry weight. Values with different letters in the same column are significantly different at $p<0.05(n=3)$.

\subsection{Antioxidant Capacity Evaluation}

The antioxidant capacity of S. tenuifolia leaf methanol extracts was determined by DPPH (2,2-diphenyl-1-picrylhydrazyl) and ABTS ${ }^{+}$(2,2'-azinobis-(3-ethylbenzothiazoline-6-sulfonic acid)) radical scavenging assay (Table 1 ). In the DPPH system, the antioxidant capacity of leaf extracts in control plants was $40.17 \%$. In response to salinity, it was found to be the highest $(62.14 \%)$ in plants treated by $25 \mathrm{mM} \mathrm{NaCl}$, then declined significantly at $50 \mathrm{mM}$ (44.79\%). Significantly, leaf extracts of plants showed a much weaker antioxidant capacity with increasing $\mathrm{NaCl}$ concentrations to 75 and $100 \mathrm{mM}$, reducing by $26 \%$ and $54 \%$, respectively, compared to the control. A similar trend was detected in $\mathrm{ABTS}^{+}$radical scavenging capacity, except that the results were insignificant at 0 and $50 \mathrm{mM} \mathrm{NaCl}$. 


\subsection{Glandular Trichome Morphology and Density}

The indumentum of S. tenuifolia includes glandular trichomes (GTs) and non-glandular trichomes (NGTs) scattered on leaf surfaces (Figures 2 and 3A,B). Considering the secreting potential, only the former type will be discussed here. The GTs are of two morphological types: peltate and capitate. Sunken in epidermal depressions, the peltate glandular trichomes (Pels) had a large spherical secretory head, $76( \pm 5) \mu \mathrm{m}$ in diameter (Figure 3C,D). The capitate glandular trichomes (Cap) are much smaller and frequently appear shriveled and collapsed (Figure 3E).
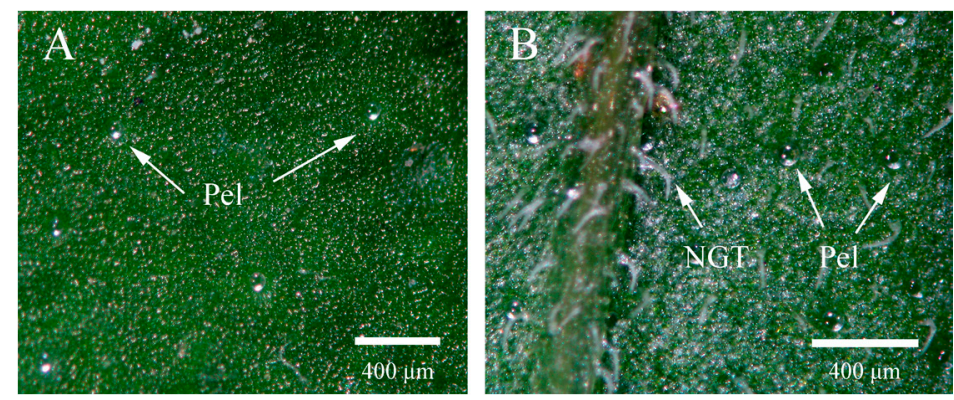

Figure 2. Stereomicroscope micrographs showing both sides of S. tenuifolia leaf. (A) Adaxial leaf surface with glandular peltate trichomes (Pels); (B) Abaxial leaf surface with non-glandular trichomes (NGTs) and glandular peltate trichome (Pels).

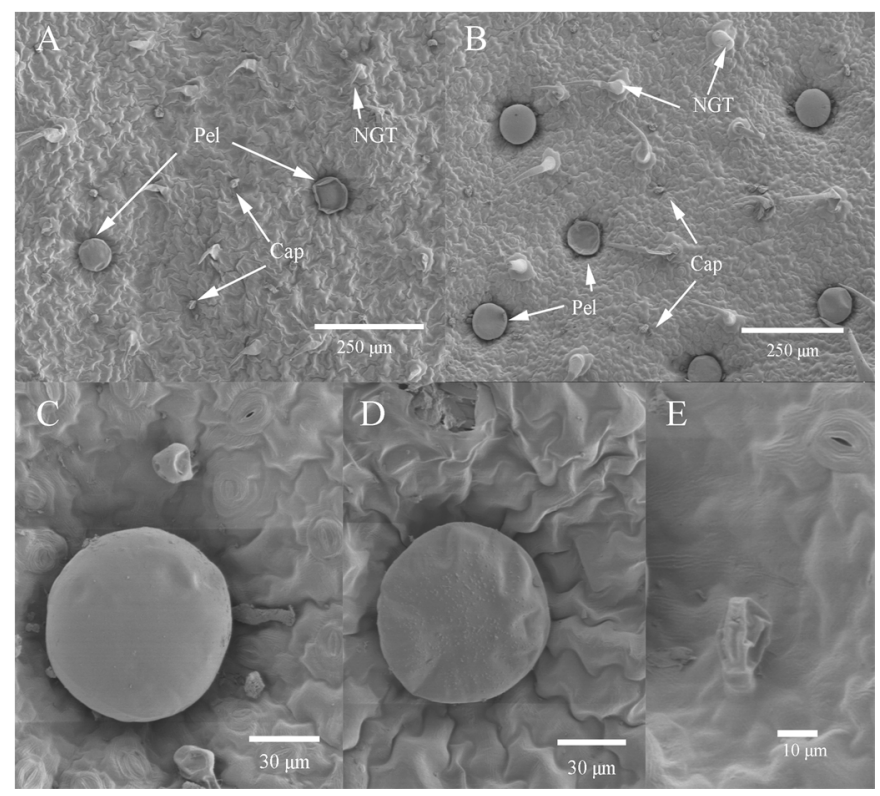

Figure 3. SEM (scanning electron microscope) micrographs showing the distribution and types of S. tenuifolia trichomes. (A) Adaxial leaf surface exhibiting three types of trichomes: non-glandular trichome (NGT), peltate glandular trichome (Pel) and capitate glandular trichome (Cap); (B) Abaxial leaf surface; (C) Peltate and capitate glandular trichomes on the leaf abaxial side; (D) Mature peltate glandular trichome; (E) Wrinkled capitate glandular trichome.

As shown in Figure 4, the Pels were less abundant on the adaxial than the abaxial side. The Caps displayed the same distribution except with treatment of $50 \mathrm{mM} \mathrm{NaCl}$. On the leaf abaxial sides, the densities of glandular trichomes of both types notably increased under moderate to severe $\mathrm{NaCl}$ concentrations compared to that of the control. The Pels on the leaf adaxial side decreased with increasing $\mathrm{NaCl}$ concentration and eventually reduced sharply at $100 \mathrm{mM} \mathrm{NaCl}$; the Caps on the adaxial side of salt treatments, except those exposed to $25 \mathrm{mM} \mathrm{NaCl}$, were more abundant than those 
of the control, and the highest density was observed at $50 \mathrm{mM} \mathrm{NaCl}$. Nevertheless, the density of total GTs of both leaf sides was noticeably enhanced by salt stress, especially at moderate to severe salinities.

A

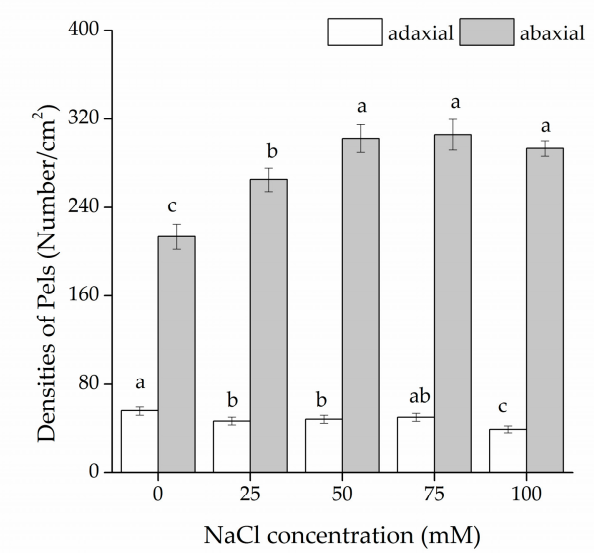

B

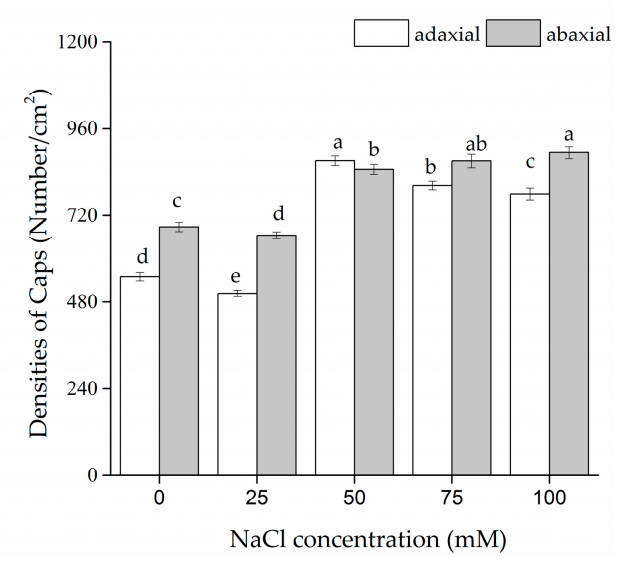

Figure 4. Effects of salt stress on the densities of glandular tricomes on leaves of S. tenuifolia. (A) Densities of Pels on both leaf surfaces; (B) Densities of Caps on both leaf surfaces. Data are expressed as the means $\pm \mathrm{SD}$. Bars filled in the same color with different letters are significantly different at $p<0.05(n=15)$.

\subsection{Constituents of Glandular Trichome Volatile Exudates in S. tenuifolia}

Compositions of GT volatile exudates of S. tenuifolia and their relative percentage (\%) at different $\mathrm{NaCl}$ levels are shown in Table 2. Fourteen compounds were identified in the control, accounting for $99.31 \%$ of the total GT volatile exudates. Pulegone (78.66\%) was the major component; other notable components were menthone (5.48\%), 2-cyclohexen-1-ol,2-methyl-5-(1-methylethenyl) (3.48\%), 1,6-cyclodecadiene,1-methyl-5-methylene-8-(1-methylethyl) $(3.02 \%), \beta$-caryophyllene $(2.27 \%)$, heptane,2,2,4,6,6-pentamethyl (2.44\%), and d-limonene (1.54\%). When exposed to salt stress, the relative proportions of these compounds were affected significantly. Compared with the control, the application of $\mathrm{NaCl}$ decreased the amounts of pulegone prominently by $19 \%, 19 \%, 39 \%$, and $61 \%$ at $25,50,75$, and $100 \mathrm{mM}$, respectively, but still remained the most abundant compound. Relative contents of 1,6-cyclodecadiene,1-methyl-5-methylene-8-(1-methylethyl) and $\beta$-caryophyllene diminished at 25 and $50 \mathrm{mM} \mathrm{NaCl}$ compared with the control; then, both compounds disappeared at 75 and $100 \mathrm{mM}$ $\mathrm{NaCl}$. The application of $25 \mathrm{mM} \mathrm{NaCl}$ did not notably change the d-limonene content with respect to the control. However, the level of $50 \mathrm{mM} \mathrm{NaCl}$ caused a significantly negative effect on its content and eventually the compound was not detected at levels of 75 and $100 \mathrm{mM}$. Menthone percentage at 25 and $50 \mathrm{mM} \mathrm{NaCl}$ was 2.14 and 1.97 times higher than that of the control, respectively, while it reduced significantly at 75 and $100 \mathrm{mM}$, especially the highest concentration. In contrast, $\mathrm{NaCl}$ stress enhanced the amounts of heptane,2,2,4,6,6-pentamethyl, 3-hexanone,2,2-dimethyl, 3-hexanone,2,5-dimethyl, and anisic acid,tridec-2-ynyl ester. It is notable that 2-cyclohexen-1-ol,2-methyl-5-(1-methylethenyl) disappeared when the plants were challenged by salt stress; while salt stress induced the biosynthesis of a new compound, sulfurous acid,2-ethylhexyl hexyl ester. As salinity increased, the amount of sulfurous acid,2-ethylhexyl hexyl ester increased remarkably and eventually became the second most abundant compound. In conclusion, GT volatile exudates in S. tenuifolia were rich in monoterpenes but they were affected negatively by salt stress. The biosynthesis of sesquiterpene, a minor class, was inhibited and then disappeared at 75 and $100 \mathrm{mM} \mathrm{NaCl}$. On the contrary, other chemical classes, especially the esters, revealed a rising trend and gradually became the dominant chemical class in salt-treated plants. 
Table 2. Compositions of glandular trichome volatile exudates in S. tenuifolia and changes of their relative percentage (\%) as affected by salt stress.

\begin{tabular}{|c|c|c|c|c|c|c|}
\hline \multirow{2}{*}{ No. } & \multirow{2}{*}{ Compounds } & \multicolumn{5}{|c|}{$\mathrm{NaCl}$ Concentration $(\mathrm{mM})$} \\
\hline & & 0 & 25 & 50 & 75 & 100 \\
\hline 1 & Heptane,2,2,4,6,6-pentamethyl & $2.44 \pm 0.07^{\mathrm{d}}$ & $7.09 \pm 0.19^{b}$ & $3.99 \pm 0.13^{c}$ & $7.4 \pm 0.18^{b}$ & $9.6 \pm 0.21^{\mathrm{a}}$ \\
\hline 2 & 3-Heptanone,5-ethyl-4-methyl & $0.21 \pm 0.01^{\mathrm{d}}$ & $0.79 \pm 0.08^{\mathrm{a}}$ & $0.34+0.03^{c}$ & $0.53 \pm 0.05^{b}$ & $0.49 \pm 0.04^{b c}$ \\
\hline 3 & D-Limonene & $1.54 \pm 0.01^{\mathrm{a}}$ & $1.6 \pm 0.01^{\mathrm{a}}$ & $0.69 \pm 0^{\mathrm{b}}$ & nd & nd \\
\hline 4 & Menthone & $5.48 \pm 0.12^{b}$ & $11.74 \pm 0.30^{\mathrm{a}}$ & $10.81 \pm 0.1^{\mathrm{a}}$ & $5.67 \pm 0.45^{b}$ & $3.1 \pm 0.09 \mathrm{bc}$ \\
\hline 5 & Anisic acid,tridec-2-ynyl ester & $1.00 \pm 0^{\mathrm{d}}$ & $3.78 \pm 0.16^{\mathrm{bc}}$ & $1.86 \pm 0.12^{c}$ & $5.38 \pm 0.19^{b}$ & $13.28 \pm 0.33^{\mathrm{a}}$ \\
\hline 6 & Pulegone & $78.66 \pm 5.01^{\mathrm{a}}$ & $63.73 \pm 4.39^{b}$ & $63.99 \pm 4.98^{b}$ & $48.1 \pm 3.26^{c}$ & $31.03 \pm 3.01 \mathrm{~d}$ \\
\hline 7 & 2-Cyclohexen-1-ol,2-methyl-5-(1-methylethenyl) & $3.48 \pm 0.09$ & nd & nd & nd & nd \\
\hline 8 & Ethanone,1-cyclopropyl-2(1-pyrrolidinyl) & nd & $0.8 \pm 0.00^{\mathrm{b}}$ & $0.93 \pm 0.01^{\mathrm{a}}$ & nd & nd \\
\hline 9 & $\beta$-Caryophyllene & $2.27 \pm 0.11^{\mathrm{a}}$ & $0.99 \pm 0.06^{\mathrm{b}}$ & $0.99 \pm 0.08^{b}$ & nd & nd \\
\hline 10 & 1,6-Cyclodecadiene,1-methyl-5-methylene-8-(1-methylethyl) & $3.02 \pm 0.14^{\mathrm{a}}$ & $1.16 \pm 0.09^{b}$ & $1.28 \pm 0.07^{\mathrm{b}}$ & nd & nd \\
\hline 11 & Glycine,N-(4-butylbenzoyl)-,butyl ester & nd & nd & nd & $0.62 \pm 0.02^{\mathrm{a}}$ & $0.1 \pm 0^{b}$ \\
\hline 12 & Ethyl propyl ketone & $0.17 \pm 0.02$ & nd & nd & nd & nd \\
\hline 13 & Sulfurous acid,isobutyl pentyl ester & nd & $0.27 \pm 0.01$ & nd & nd & nd \\
\hline 14 & Hexanedioic acid,bis(2-ethylhexyl) ester & nd & nd & $2.29 \pm 0.14^{\mathrm{a}}$ & $1.44 \pm 0.10^{\mathrm{b}}$ & $1.76 \pm 0.13^{b}$ \\
\hline 15 & 2,2'-Methylenebis(6-tert-butyl-4-methyl-phenol) & $0.27 \pm 0.04^{b}$ & nd & $1.86 \pm 0.19^{\mathrm{a}}$ & $0.22 \pm 0.23^{b}$ & $1.86 \pm 0.20^{\mathrm{a}}$ \\
\hline 16 & 3-Hexanone,2,2-dimethyl & $0.23 \pm 0.011^{\mathrm{e}}$ & $1.03 \pm 0.08^{b}$ & $0.5 \pm 0.02^{d}$ & $0.92 \pm 0.07 \mathrm{bc}$ & $2.16 \pm 0.15^{\mathrm{a}}$ \\
\hline 17 & 1,4-Butanediol & $0.09 \pm 0.00^{\mathrm{d}}$ & $0.21 \pm 0.01^{\mathrm{c}}$ & $0.25 \pm 0.01^{c}$ & $0.39 \pm 0.03^{b}$ & $0.62 \pm 0.07^{\mathrm{a}}$ \\
\hline 18 & 3-Hexanone,2,5-dimethyl & $0.45 \pm 0.03^{\mathrm{cd}}$ & $0.69 \pm 0.08^{c}$ & $1.41 \pm 0.12^{b}$ & $4.03 \pm 0.22^{\mathrm{a}}$ & $4.84 \pm 0.22^{\mathrm{a}}$ \\
\hline \multirow[t]{9}{*}{19} & Sulfurous acid,2-ethylhexyl hexyl ester & nd & $5.73 \pm 0.71$ bc & $7.93 \pm 0.87^{b}$ & $24.81 \pm 2.71^{\mathrm{a}}$ & $26.70 \pm 2.69^{a}$ \\
\hline & Total & 99.31 & 99.61 & 99.12 & 99.51 & 98.70 \\
\hline & Total identified classes & & & & & \\
\hline & Alkane & $2.44 \pm 0.36^{\mathrm{d}}$ & $7.09 \pm 0.58^{b}$ & $3.99 \pm 0.41^{\mathrm{c}}$ & $7.4 \pm 0.61^{b}$ & $9.6 \pm 0.78^{a}$ \\
\hline & Ketones & $1.06 \pm 0.09 \mathrm{~d}$ & $3.31 \pm 0.24^{\mathrm{c}}$ & $3.18 \pm 0.21^{\mathrm{c}}$ & $5.48 \pm 0.25^{b}$ & $9.64 \pm 0.81^{\mathrm{a}}$ \\
\hline & Monoterpenes & $89.16 \pm 3.44^{\mathrm{a}}$ & $77.07 \pm 3.06^{b}$ & $75.49 \pm 2.71^{b}$ & $53.77 \pm 1.98^{c}$ & $34.13 \pm 1.65^{\mathrm{d}}$ \\
\hline & Esters & $1.00 \pm 0.10^{\mathrm{e}}$ & $9.78 \pm 1.51^{\mathrm{cd}}$ & $12.08 \pm 1.78^{c}$ & $32.25 \pm 2.13^{b}$ & $42.85 \pm 3.04^{\mathrm{a}}$ \\
\hline & Sesquiterpene & $5.29 \pm 0.56^{\mathrm{a}}$ & $2.15 \pm 0.31^{b}$ & $2.27 \pm 0.35^{b}$ & $0^{\mathrm{c}}$ & $0^{\mathrm{c}}$ \\
\hline & Others & $0.36 \pm 0.04^{\mathrm{d}}$ & $0.21 \pm 0.02^{\mathrm{d}}$ & $2.11 \pm 0.16^{\mathrm{ab}}$ & $0.61 \pm 0.02^{c}$ & $2.48 \pm 0.20^{\mathrm{a}}$ \\
\hline
\end{tabular}

Values with different letters in the same row are significantly different at $p<0.05(n=3)$. nd: not detected. 
Principle component analysis (PCA) was conducted to determine the relationship between different salt concentrations based on GT volatile exudate compositions (Figure 5). A clear distinction was revealed in the box plot of scores in three principle components. Firstly, the control $(0 \mathrm{mM} \mathrm{NaCl})$ was highly deviated from salt treatments. Secondly, salt levels of 25 and $50 \mathrm{mM} \mathrm{NaCl}$ formed a group. Higher levels of 75 and $100 \mathrm{mM} \mathrm{NaCl}$ formed the third group.

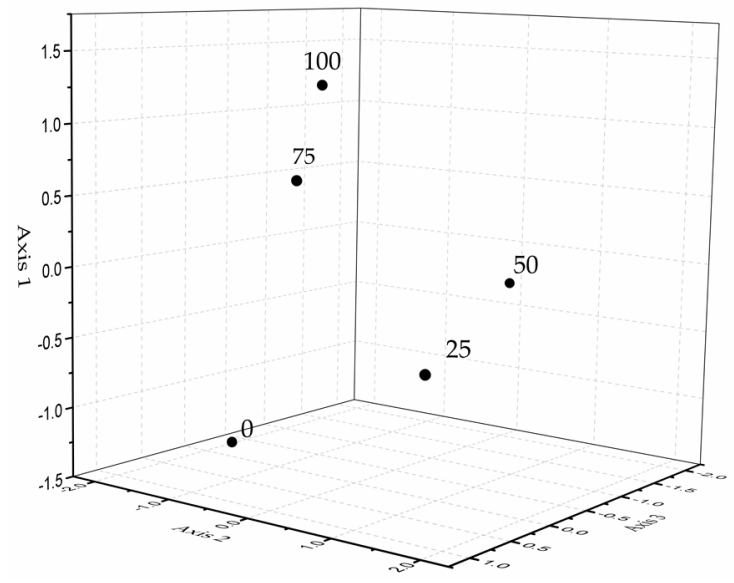

Figure 5. Relative position of five salt treatments $(0,25,50,75,100 \mathrm{mM} \mathrm{NaCl})$ in the space defined by three principle components.

\section{Discussion}

In this investigation, S. tenuifolia growth was inhibited by salt stress in terms of plant height. Considering that no negative effect was found on the accumulation of dry matter by the application of $25 \mathrm{mM} \mathrm{NaCl}$, it appears that $S$. tenuifolia can be tolerant to mild salinity, while plant height depressed remarkably at higher concentrations. Several authors have reported the reduction of biomass induced by salt stress in other medicinal and aromatic plants [27-29]. This inhibitory effect was probably due to the impact of salt on the stomata and photosynthesis process, as intercellular $\mathrm{CO}_{2}$ concentration was reduced and photosynthetic enzymes, chlorophylls, and carotenoids were disturbed, respectively [23].

The results showed that accumulation of the phenolics was induced under mild salinity $(25 \mathrm{mM})$ but depressed under severe treatments $(75$ and $100 \mathrm{mM})$. It is well established that abiotic stresses including salinity cause oxidative damages, mainly by generating excess ROS (reactive oxygen species), which can attack lipids, proteins, DNA, and carbohydrates. The ROS is comprised of both non-radical (molecular) $\left({ }^{1} \mathrm{O}_{2}\right.$ and $\left.\mathrm{H}_{2} \mathrm{O}_{2}\right)$ and free radical forms $\left(\mathrm{OH} \bullet, \mathrm{O}_{2} \bullet{ }^{-}\right.$, $\mathrm{RO} \bullet$ and $\left.\mathrm{HO}_{2} \bullet\right)$ [30]. In order to scavenge or detoxify ROS, antioxidants such as phenolic compounds are produced by plants [31], and this is why the biosynthesis of such compounds is generally stimulated in salt-exposed plants [32]. However, the accumulation of phenolics under salinity conditions may vary in different plant species. In previous reports, the volume of phenolic compounds increased in buckwheat sprout [33], Salvia mirzayanii [34], and Carthamus tinctorius flowers [35] under $\mathrm{NaCl}$ stress, but failed to accumulate in coriander fruits [25] and baby Romaine lettuce [36] in response to $\mathrm{NaCl}$ treatments. A relative tolerance of $S$. tenuifolia to $25 \mathrm{mM} \mathrm{NaCl}$ was indicated as phenolic contents increased at that level. At 75 and $100 \mathrm{mM} \mathrm{NaCl}$, scavenging ROS is inefficient by virtue of the imbalance between antioxidants formation and ROS. Oxidative damage such as leaf chlorosis and necrosis was consequently caused. Besides, increasing evidence suggested that flavonoids in higher plants have the potential to serve as antioxidants in response to environmental stresses including salinity [37-41]. It has been hypothesized that the biosynthesis of flavonoids, especially flavonol, can be stimulated by the changes of the cellular redox homeostasis [42] as MYB (myeloblastosis) transcription factors, which are involved in flavonol biosynthesis, are regulated by varied cellular redox potentials [43-45]. Changes in the overall results of DPPH and ABTS tests were similar to those observed in TPC. These antioxidant 
capacities may be directly linked with the amounts of phenolic compounds because of their free radical scavenging capacities [46,47]. Furthermore, in buckwheat sprout [33], maize [48], and some Chinese medicinal plants [49], total phenolic amounts were significantly correlated with antioxidant capacity.

Peltate (Pel) and capitate (Cap) glandular tricomes were observed on both leaf surfaces; this was considered as a common arrangement in the Lamiaceae family [50]. Compared to the Pels, the Caps were much smaller and most were shriveled and collapsed, demonstrating an apparently relatively short-lived property [51]. Regardless of the leaf side of S. tenuifolia, the Caps are distributed densely and the Pels scattered among them, as described in Menta pulegium [52,53]. Generally, Pels and Caps were more abundant on the abaxial than the adaxial side. When exposed to salt stress, the density of total GTs of both leaf sides increased, especially at moderate to severe salinities. As to data, there is very little available data on the effect of salt on the density of GT on leaf surfaces, particularly in Lamiaceae plants. Only one previous study showed that application of $50 \mathrm{mM} \mathrm{NaCl}$ improved the density of GTs on leaves of M. pulegium [52]. The increase of GT density can be explained by the fact that salt-treated (50-100 $\mathrm{mM} \mathrm{NaCl}$ ) plants exhibited less leaf area compared to that of the control, considering the fact that trichomes or oil glands are genetically fixed [54,55]. Could the increase of GT density in S. tenuifolia under salt stress improve EO yield? This is the next step of our research.

In this experiment, the GT volatile exudates of S. tenuifolia treated by salt stress were extracted by methylene chloride $\left(\mathrm{CH}_{2} \mathrm{Cl}_{2}\right)$. According to Wagner et al. [56], washing leaf surfaces with $\mathrm{CH}_{2} \mathrm{Cl}_{2}$ can quickly and completely remove large quantities of GT exudates. Moreover, rapid rinsing with $\mathrm{CH}_{2} \mathrm{Cl}_{2}$ does not visibly penetrate the epidermis, i.e., it appears not to extract internal leaf metabolites. It is, therefore, convenient and efficient to study the impacts of salt stress on the aspect of GT secondary metabolism in this method as compared to steam distillation.

As previously mentioned in S. tenuifolia EO, common components including pulegone (the most abundant compound), menthone, and d-limonene in GT volatile exudates were detected. However, relative percentages of these and other compounds underwent significant changes under salt stress. We found that proportions of pulegone declined with increasing salt concentrations. Pulegone was derived from d-limonene by a series of steps; it serves as a precursor for the production of methone by pulegone reductase (PR) [57]. In addition to the decrement of d-limonene, the decrease of pulegone could be due to the salt-induced negative impacts on the activity of related biosynthesis enzymes responsible for converting $d$-limonene to pulegone. The production of menthone was stimulated at mild and moderate salinity while it was inhibited by the most severe salt treatment; this may be related to the changes of PR activity under salt treatment. Terpenes including 1,6-cyclodecadiene,1-methyl-5-methylene-8-(1-methylethyl), $\beta$-caryophyllene, and d-limonene were not even detected at 75 and $100 \mathrm{mM}$. The amount of other compounds such as heptane,2,2,4,6,6-pentamethyl, 3-hexanone,2,2-dimethyl, 3-hexanone,2,5-dimethyl, and anisic acid,tridec-2-ynyl ester were increased by salinity. Moreover, a new compound, sulfurous acid,2-ethylhexyl hexyl ester, appeared under salt stress and eventually became the second most abundant compound, suggesting that salt stress has significant effects on the ester metabolic pathways of S. tenuifolia. We found that those variations were based on relative proportions of some constituents, as well as the absence of particular components or the presence of new ones. Consequently, results from the PCA indicated that the GT volatile exudates in S. tenuifolia are sensitive to salt stress, and this influence was dose-dependent. Since the essential oil is biosynthesized and stored in GT [58,59], the above phenomena alert us to investigate how salt stress influences the essential oil yield and components of S. tenuifolia and its medicinal and edible properties.

\section{Materials and Methods}

\subsection{Plant Material and Salt Treatments}

We performed this experiment in a greenhouse of the College of Horticulture, Nanjing Agricultural University, Nanjing, China. Plants were cultivated under a natural light condition with $30{ }^{\circ} \mathrm{C}$ day 
maximum and $15{ }^{\circ} \mathrm{C}$ night minimum, and $60-80 \%$ air humidity. Schizonepeta tenuifolia Briq. seeds were bought from Xincheng Chinese Herbal Medicine Industry (Anguo, China). In March, 2017, seeds were sown in trays containing a compost of humus, vermiculite, and perlite (1:2:1) and irrigated with distilled water to keep moist. About 8 days later, seeds were germinated and quarter-strength modified Hoagland's solution [60] was used for irrigation. Thirty-seven days later (establishment phase), homogenous plants with a height of nearly $15 \mathrm{~cm}$ were transplanted into plastic pots filled with pure quartz sand. Two plants were cultivated in each pot and irrigated with $200 \mathrm{~mL}$ half-strength modified Hoagland's solution every second day. Six days later, the plants were divided into five groups and salt treatments were initiated. A total of $300 \mathrm{~mL}$ of the above nutrient solution supplemented with $0,25,50,75$, or $100 \mathrm{mM} \mathrm{NaCl}$ was applied every day. To prevent osmotic shock, salt concentrations increased gradually with $25 \mathrm{mM} \mathrm{NaCl}$ every other day until the designated concentration was reached. The experimental design was completely randomized with 70 individuals for each treatment. All plants were harvested after 12 days since salt stress symptoms (leaf chlorosis and necrosis) occurred, especially in those treated with 75 and $100 \mathrm{mM} \mathrm{NaCl}$.

\subsection{Chemicals}

Folin-Ciocalteu reagent, gallic acid (GA) and rutin were purchased from Yuanye Bio-Technology Co. (Shanghai, China). 2,2'-azinobis-(3-ethylbenzothiazoline-6-sulfonic acid) (ABTS) and 2,2-diphenyl-1-picrylhydrazyl (DPPH) were purchased from TCI Development Co. (Shanghai, China). All other reagents were purchased from Xilong Scientific Co. (Guangzhou, China).

\subsection{Plant Growth Parameters}

Ten individual plants for each treatment were collected to record the plant height and fresh weight. Their dry weight was measured after being oven-dried at $50{ }^{\circ} \mathrm{C}$ for five days.

\subsection{Polyphenol Extraction and Analysis}

\subsubsection{Preparation of Extracts}

Plant leaves of all treatments were dried at room temperature. Triplicate samples of $0.5 \mathrm{~g}$ dry power for each treatment were milled with $10 \mathrm{~mL}$ methanol solution $(80 \%)$ and then ultrasonically extracted for $30 \mathrm{~min}$. The mixtures were centrifuged on $4000 \times \mathrm{g}$ at $4{ }^{\circ} \mathrm{C}$ for $30 \mathrm{~min}$ [61]. The supernatant was collected and then stored at $4{ }^{\circ} \mathrm{C}$ for evaluating contents of total phenolics and flavonoids as well as antioxidant capacity of the methanolic extracts (within $48 \mathrm{~h}$ ).

\subsubsection{Determination of Total Phenolic Content (TPC)}

The Folin-Ciocalteu reagent was used to determine the content of total phenolics [62]. Briefly, $3.6 \mathrm{~mL}$ of $\mathrm{ddH}_{2} \mathrm{O}, 0.4 \mathrm{~mL}$ of diluted sample extract, and $0.4 \mathrm{~mL}$ of Folin-Ciocalteu reagent were added sequentially to a $10-\mathrm{mL}$ volumetric flask. After $5 \mathrm{~min}, 4 \mathrm{~mL}$ of $7 \% \mathrm{Na}_{2} \mathrm{CO}_{3}$ solution was added. The solution was immediately made up to $10 \mathrm{~mL}$ with $\mathrm{ddH}_{2} \mathrm{O}$ and then incubated at $23^{\circ} \mathrm{C}$ for $90 \mathrm{~min}$. The absorbance was measured at $750 \mathrm{~nm}$ against a $\mathrm{ddH}_{2} \mathrm{O}$ blank. A standard curve was established by gallic acid (GA). Results were expressed as mg of GA equivalents on a basis of dry weight (mg GAE/g DW). All samples were analyzed in triplicate.

\subsubsection{Determination of Total Flavonoid Content (TFC)}

The total amount of flavonoids was measured according to a modified spectrophotometric method described by Siddhuraju and Becker [63]. Prepared diluted sample $(1 \mathrm{~mL})$, distilled water $(3 \mathrm{~mL})$, and $5 \% \mathrm{NaNO}_{2}(0.3 \mathrm{~mL})$ were placed in a volumetric flask $(10 \mathrm{~mL})$ and held for $5 \mathrm{~min}$. Then, $1 \%$ $\mathrm{AlCl}_{3}$ solution $(3 \mathrm{~mL}$ ) was added. After $6 \mathrm{~min}, 2 \mathrm{~mL}$ of $1 \mathrm{M} \mathrm{NaOH}$ solution was added. The reaction solution was finally diluted to $10 \mathrm{~mL}$ with distilled water and thoroughly mixed. Absorbance of the resulting solution was read at $510 \mathrm{~nm}$ against a water blank. Rutin was used to develop a standard 
curve. Total flavonoid content of samples was expressed as mg of rutin equivalents on a basis of dry weight (mg rutin/g DW). All samples were analyzed in triplicate.

\subsection{Antioxidant Capacity Evaluation}

\subsubsection{DPPH Radical Scavenging Activity}

DPPH radical scavenging assay was performed following the method of Chrysargyris et al. [61]. A total of $0.02 \mathrm{~mL}$ leaf extract, $1.98 \mathrm{~mL} 80 \%$ methanol, and $1 \mathrm{~mL}$ purple DPPH solution $(0.3 \mathrm{mM})$ were mixed and held for $30 \mathrm{~min}$ at room temperature in the dark. Absorbance of the solution at $517 \mathrm{~nm}$ was measured. The test was carried out in triplicate and results were presented as the inhibition percentage (\%) and calculated by a given formula:

DPPH radical scavenging activity $\%=100-100 \times\left[\left(\mathrm{Ab}_{\text {sample }}-\mathrm{Ab}_{\text {blank }}\right) / \mathrm{Ab}_{\text {control }}\right]$

where $A b_{\text {sample }}$ is the absorbance of the test sample, $A b_{\text {blank }}$ is the absrbance of the blank sample and $\mathrm{Ab}_{\text {control }}$ is the absorbance of the control with DPPH and $80 \%$ menthol.

\subsection{2. $\mathrm{ABTS}^{++}$Radical Scavenging Activity}

$\mathrm{ABTS}^{+}$radical scavenging assay was conducted using a modified method of Cai et al. [64]. Briefly, $2.45 \mathrm{mM}$ potassium persulfate solution and $7 \mathrm{mM}$ ABTS stock solution were reacted at a ratio of 0.5:1, and then they were left standing for 12-16 h in the dark at ambient temperature to generate ABTS radical cations $\left(\mathrm{ABTS}^{+}\right)$. The absorbance of $\mathrm{ABTS}^{+}$solution was adjusted with the addition of $80 \%$ ethanol until $0.700 \pm 0.05$ was read at $734 \mathrm{~nm}$. Prepared $0.1 \mathrm{~mL}$ diluted leaf extract was reacted with $3.9 \mathrm{~mL}$ blue-green $\mathrm{ABTS}^{+}$solution. The absorbance at $734 \mathrm{~nm}$ of the resulting solution was recorded after $6 \mathrm{~min}$. Trolox standard solution was employed to establish a standard calibration. The test was carried out in triplicate and results were expressed as trolox equivalent antioxidant capacity ( $\mu \mathrm{mol}$ of trolox equivalent antioxidant capacity on a basis of dry weight, $\mu$ mol TEAC/g DW).

\subsection{Glandular Trichome Morphology and Density}

Fresh leaf samples at the second node (from the apex) were carefully cut and any damage to the surfaces was avoided. Adaxial and abaxial leaf sides were observed with a Zeiss Stemi 2000-C stereomicroscope (SM) (Carl Zeiss Ltd., Jena, Germany) coupled with a digital camera (Canon Inc., Tokyo, Japan) for identifying glandular trichomes (GTs). A Hitachi SU8010 scanning electron microscope (SEM) (Hitachi Science System Ltd., Naka, Japan) was also used for structural details and determining glandular trichome (GT) density of both sides, and the determination was repeated fifteen times.

\subsection{Extraction of Glandular Trichome Volatile Exudates}

Extraction of GT volatile exudates was conducted following a modified version of the methods of Severson et al. [65] and Asai and Fujimoto [66]. Fresh fully extended leaves (4 g) for each treatment were collected. Three 100-mL beakers containing $50 \mathrm{~mL}$ methylene chloride $\left(\mathrm{CH}_{2} \mathrm{Cl}_{2}\right)$ in each were prepared. The samples were dipped into the first beaker four times; they were kept submerged in $\mathrm{CH}_{2} \mathrm{Cl}_{2}$ for about $2 \mathrm{~s} /$ dip. Excess $\mathrm{CH}_{2} \mathrm{Cl}_{2}$ was allowed to run off after the fourth dip. The same procedure was performed in the other two beakers. The extracts were subjected to vacuum suction filtration (20 g anhydrous $\mathrm{Na}_{2} \mathrm{SO}_{4}$ was placed on the filter paper) into a clean filtering flask. Filter papers and the three beakers were washed twice with $\mathrm{CH}_{2} \mathrm{Cl}_{2}$ (about $150 \mathrm{~mL}$ ). All $\mathrm{CH}_{2} \mathrm{Cl}_{2}$ extracts and washings were mixed in a round-bottom flask and then concentrated to $10 \mathrm{~mL}$ under reduced pressure at $38^{\circ} \mathrm{C}$. The concentrated solution was stored at $0{ }^{\circ} \mathrm{C}$ in the dark until analysis. Triplicate extractions were carried out for each treatment. 


\subsection{Gas Chromatography/Mass Spectrometry Analysis of GT Volatile Exudates and Compound Identification}

GT volatile exudates were analyzed using a Shimadzu GC2010 gas chromatograph, interfaced with a Shimadzu QP2010 plus mass spectrometer (Shimadzu Corp., Kyoto, Japan). A RTX-5ms capillary column $(30 \mathrm{~m} \times 0.25 \mathrm{~mm}, 0.25 \mu \mathrm{m}$ film thickness) (Restek, Bellefonte, PA, USA) was used. Samples of $1 \mu \mathrm{L}$ were injected automatically and the split ratio was 20:1. Helium was the carrier gas with a flow rate of $1.3 \mathrm{~mL} / \mathrm{min}$. The temperature program was as follows: initial temperature was $50{ }^{\circ} \mathrm{C}$, increased to $90^{\circ} \mathrm{C}$ at $10^{\circ} \mathrm{C} / \mathrm{min}$, and maintained for $5 \mathrm{~min}$; increased to $160^{\circ} \mathrm{C}$ at $10^{\circ} \mathrm{C} / \mathrm{min}$ and maintained for $10 \mathrm{~min}$; increased to $250^{\circ} \mathrm{C}$ at $10^{\circ} \mathrm{C} / \mathrm{min}$ and then maintained for $10 \mathrm{~min}$. The injection temperature was $230^{\circ} \mathrm{C}$. The scan mass range was $40-800 \mathrm{~m} / \mathrm{z}$. A mass spectrometer was operated in the electron impact mode $(70 \mathrm{eV})$. Compounds were identified by their unique retention indices (RI) according to the NIST05 mass spectral library. Their relative percentage was determined based on peak area normalization with no correction factors used.

\subsection{Statistical Analysis}

Data were statistically analyzed by IBM SPSS v. 19.0 (IBM SPSS Statistics Inc., Chicago, IL, USA) and presented as treatment mean \pm standard deviation (SD). One-way analysis of variance (ANOVA) followed by Duncan range test was used to compare the means. For all statistical analysis, 0.05 was set as the significance level. A principal component analysis (PCA) was performed on the basis of the total peak area of detected GT volatile exudates to discriminate between different $\mathrm{NaCl}$ concentrations.

\section{Conclusions}

In response to increasing salinity, the dry biomass of $S$. tenuifolia decreased. The accumulation of antioxidants, including phenolics and flavonoids, was enhanced by low or moderate levels of salinity but inhibited by severe levels. Changes in the antioxidant capacity of leaf extracts were similar to those in the TPC. On both leaf surfaces, glandular trichomes (GTs) of two types were found: big peltate and small capitate. The density of total GTs on both leaf sides increased under salinities, especially under moderate to severe treatments. Salt stress significantly affected the constituents of GT volatile exudates in S. tenuifolia. The most abundant compound in GT volatile exudates was pulegone. The decrease, or even disappearance, of monoterpenes was induced by salt stress, while biosynthesis and accumulation of esters, especially sulfurous acid,2-ethylhexyl hexyl ester, were enhanced. Biochemical and GT density changes under salinity could reflect an adaption response of S. tenuifolia to this factor. In this case, salinity conditions should be avoided for the cultivation of S. tenuifolia due to the decrease of the marker compound, pulegone. However, mild salinity can be recommended to produce antioxidant compounds.

Acknowledgments: This work was supported by the State Administration of Traditional Chinese Medicine of the People's Republic of China (grant number 201407002).

Author Contributions: Xiaoqing Tang and Kangcai Wang conceived and designed the experiments. Ying Zhou, Nanyu Tang, Lijin Huang, and Yongjuan Zhao performed the experiments. Ying Zhou analyzed the data and drafted the manuscript. All authors contributed to the revision of this manuscript and approved the final manuscript.

Conflicts of Interest: The authors declare no conflict of interest. 


\section{Abbreviations}

$\begin{array}{ll}\text { EO } & \text { essential oil } \\ \text { TPC } & \text { total phenolic content } \\ \text { TFC } & \text { total flavonoid content } \\ \text { NGT } & \text { non-glandular trichome } \\ \text { GT } & \text { glandular trichome } \\ \text { Pel } & \text { peltate glandular trichome } \\ \text { Cap } & \text { capitate glandular trichomes } \\ \text { SEM } & \text { scanning electron microscope }\end{array}$

\section{References}

1. Chun, M.H.; Kim, E.K.; Yu, S.M.; Oh, M.S.; Moon, K.Y.; Jung, J.H.; Hong, J. GC/MS combined with chemometrics methods for quality control of Schizonepeta tenuifolia Briq: Determination of essential oils. Microchem. J. 2011, 97, 274-281. [CrossRef]

2. Fung, D.; Lau, C.B.S. Schizonepeta tenuifolia: Chemistry, pharmacology, and clinical applications. J. Clin. Pharmacol. 2002, 42, 30-36. [CrossRef] [PubMed]

3. Chen, S.G.; Cheng, M.L.; Chen, K.H.; Horng, J.T.; Liu, C.C.; Wang, S.M.; Sakurai, H.; Leu, Y.L.; Wang, S.D.; Ho, H.Y. Antiviral activities of Schizonepeta tenuifolia Briq. against enterovirus 71 in vitro and in vivo. Sci. Rep. 2017, 7, 935. [CrossRef] [PubMed]

4. Tohda, C.; Kakihara, Y.; Komatsu, K.; Kuraishi, Y. Inhibitory effects of methanol extracts of herbal medicines on substance P-induced itch-scratch response. Biol. Pharm. Bull. 2000, 23, 599-601. [CrossRef] [PubMed]

5. Wang, B.S.; Huang, G.J.; Tai, H.M.; Huang, M.H. Antioxidant and anti-inflammatory activities of aqueous extracts of Schizonepeta tenuifolia Briq. Food Chem. Toxicol. 2012, 50, 526-531. [CrossRef] [PubMed]

6. Shan, M.Q.; Qian, Y.; Yu, S.; Guo, S.C.; Zhang, L.; Ding, A.W.; Wu, Q.N. Anti-inflammatory effect of volatile oil from Schizonepeta tenuifolia on carrageenin-induced pleurisy in rats and its application to study of appropriate harvesting time coupled with multi-attribute comprehensive index method. J. Ethnopharmacol. 2016, 194, 580-586. [CrossRef] [PubMed]

7. Choi, I.H.; Park, J.Y.; Shin, S.C.; Kim, J.; Park, I.K. Nematicidal activity of medicinal plant essential oils against the pinewood nematode (Bursaphelenchus xylophilus). Appl. Entomol. Zool. 2007, 42, 397-401. [CrossRef]

8. Park, I.K.; Kim, L.S.; Choi, I.H.; Lee, Y.S.; Shin, S.C. Fumigant activity of plant essential oils and components from Schizonepeta tenuifolia against Lycoriella ingenua (Diptera: Sciaridae). J. Econ. Entomol. 2006, 99, 1717-1721. [CrossRef] [PubMed]

9. Bozovic, M.; Ragno, R. Calamintha nepeta (L.) Savi and its main essential oil constituent pulegone: Biological activities and chemistry. Molecules 2017, 22, 290. [CrossRef] [PubMed]

10. Chinese Pharmacopoeia Commission. The Pharmacopoeia of the People's Republic of China 1; China Medical Science Press: Beijing, China, 2015; p. 232. (In Chinese)

11. Sun, J. D-Limonene: Safety and clinical applications. Altern. Med. Rev. 2007, 12, 259. [PubMed]

12. Miyazawa, M.; Nakanishi, K. Biotransformation of (-)-menthone by human liver microsomes. Biosci. Biotechnol. Biochem. 2006, 70, 1259-1261. [CrossRef] [PubMed]

13. Yu, S.; Chen, Y.W.; Zhang, L.; Shan, M.Q.; Tang, Y.P.; Ding, A.W. Quantitative comparative analysis of the bio-active and toxic constituents of leaves and spikes of Schizonepeta tenuifolia at different harvesting times. Int. J. Mol. Sci. 2011, 12, 6635-6644. [CrossRef] [PubMed]

14. Fahn, A. Secretory Tissues in Vascular Plants. New Phytol. 1988, 108, 229-257. [CrossRef]

15. Johnson, S.R.; Lange, I.; Srividya, N.; Lange, B.M. Bioenergetics of monoterpenoid essential oil biosynthesis in nonphotosynthetic glandular trichomes. Plant Physiol. 2017, 175, 681-695. [PubMed]

16. Gersbach, P.V. The essential oil secretory structures of Prostanthera ovalifolia (Lamiaceae). Ann. Bot. 2002, 89, 255-260. [CrossRef] [PubMed]

17. Tissier, A. Glandular trichomes what comes after expressed sequence tags? Plant J. 2012, 70, 51-68. [CrossRef] [PubMed]

18. Zhao, G.M.; Han, Y.; Sun, X.; Li, S.H.; Shi, Q.M.; Wang, C.H. Salinity stress increases secondary metabolites and enzyme activity in safflower. Ind. Crop. Prod. 2015, 64, 175-181.

19. Zhu, J.K. Plant salt tolerance. Trends Plant Sci. 2001, 6, 66-71. [CrossRef] 
20. Aghaei, K.; Komatsu, S. Crop and medicinal plants proteomics in response to salt stress. Front. Plant Sci. 2013, 4, 8. [CrossRef] [PubMed]

21. Wink, M. Modes of action of herbal medicines and plant secondary metabolites. Medicines 2015, 2, 251-286. [CrossRef] [PubMed]

22. Selmar, D.; Kleinwachter, M. Influencing the product quality by deliberately applying drought stress during the cultivation of medicinal plants. Ind. Crop. Prod. 2013, 42, 558-566. [CrossRef]

23. Taârit, M.B.; Msaada, K.; Hosni, K.; Marzouk, B. Physiological changes, phenolic content and antioxidant activity of Salvia officinalis L. grown under saline conditions. J. Sci. Food Agric. 2012, 92, 1614-1619. [CrossRef] [PubMed]

24. Ksouri, R.; Megdiche, W.; Debez, A.; Falleh, H.; Grignon, C.; Abdelly, C. Salinity effects on polyphenol content and antioxidant activities in leaves of the halophyte Cakile maritima. Plant Physiol. Biochem. 2007, 45, 244-249. [CrossRef] [PubMed]

25. Neffati, M.; Sriti, J.; Hamdaoui, G.; Kchouk, M.E.; Marzouk, B. Salinity impact on fruit yield, essential oil composition and antioxidant activities of Coriandrum sativum fruit extracts. Food Chem. 2011, 124, 221-225. [CrossRef]

26. Glas, J.J.; Schimmel, B.C.J.; Alba, J.M.; Escobar-Bravo, R.; Schuurink, R.C.; Kant, M.R. Plant glandular trichomes as targets for breeding or engineering of resistance to herbivores. Int. J. Mol. Sci. 2012, 13, 17077-17103. [CrossRef] [PubMed]

27. Ashraf, M.; Orooj, A. Salt stress effects on growth, ion accumulation and seed oil concentration in an arid zone traditional medicinal plant ajwain (Trachyspermum ammi [L.] Sprague). J. Arid Environ. 2006, 64, $209-220$. [CrossRef]

28. Oueslati, S.; Karray-Bouraoui, N.; Attia, H.; Rabhi, M.; Ksouri, R.; Lachaal, M. Physiological and antioxidant responses of Mentha pulegium (Pennyroyal) to salt stress. Acta Physiol. Plant 2010, 32, 289-296. [CrossRef]

29. Rebey, I.B.; Bourgou, S.; Rahali, F.Z.; Msaada, K.; Ksouri, R.; Marzouk, B. Relation between salt tolerance and biochemical changes in cumin (Cuminum cyminum L.) seeds. J. Food Drug Anal. 2017, 25, 391-402. [CrossRef] [PubMed]

30. Gill, S.S.; Tuteja, N. Reactive oxygen species and antioxidant machinery in abiotic stress tolerance in crop plants. Plant Physiol. Biochem. 2010, 48, 909-930. [CrossRef] [PubMed]

31. Petridis, A.; Therios, I.; Samouris, G.; Tananaki, C. Salinity-induced changes in phenolic compounds in leaves and roots of four olive cultivars (Olea europaea L.) and their relationship to antioxidant activity. Environ. Exp. Bot. 2012, 79, 37-43. [CrossRef]

32. Navarro, J.M.; Flores, P.; Garrido, C.; Martinez, V. Changes in the contents of antioxidant compounds in pepper fruits at different ripening stages, as affected by salinity. Food Chem. 2006, 96, 66-73. [CrossRef]

33. Lim, J.H.; Park, K.J.; Kim, B.K.; Jeong, J.W.; Kim, H.J. Effect of salinity stress on phenolic compounds and carotenoids in buckwheat (Fagopyrum esculentum M.) sprout. Food Chem. 2012, 135, 1065-1070. [CrossRef] [PubMed]

34. Valifard, M.; Mohsenzadeh, S.; Kholdebarin, B.; Rowshan, V. Effects of salt stress on volatile compounds, total phenolic content and antioxidant activities of Salvia mirzayanii. S. Afr. J. Bot. 2014, 93, 92-97. [CrossRef]

35. Salem, N.; Msaada, K.; Dhifi, W.; Limam, F.; Marzouk, B. Effect of salinity on plant growth and biological activities of Carthamus tinctorius L. extracts at two flowering stages. Acta Physiol. Plant 2014, 36, 433-445. [CrossRef]

36. Chisari, M.; Todaro, A.; Barbagallo, R.N.; Spagna, G. Salinity effects on enzymatic browning and antioxidant capacity of fresh-cut baby Romaine lettuce (Lactuca sativa L. cv. Duende). Food Chem. 2010, 119, 1502-1506. [CrossRef]

37. Agati, G.; Azzarello, E.; Pollastri, S.; Tattini, M. Flavonoids as antioxidants in plants: Location and functional significance. Plant Sci. 2012, 196, 67-76. [CrossRef] [PubMed]

38. Agati, G.; Biricolti, S.; Guidi, L.; Ferrini, F.; Fini, A.; Tattini, M. The biosynthesis of flavonoids is enhanced similarly by UV radiation and root zone salinity in L. vulgare leaves. J. Plant Physiol. 2011, 168, 204-212. [CrossRef] [PubMed]

39. Babu, T.S.; Akhtar, T.A.; Lampi, M.A.; Tripuranthakam, S.; Dixon, D.G.; Greenberg, B.M. Similar stress responses are elicited by copper and ultraviolet radiation in the aquatic plant Lemna gibba: Implication of reactive oxygen species as common signals. Plant Cell Physiol. 2003, 44, 1320-1329. [CrossRef] [PubMed] 
40. Tattini, M.; Remorini, D.; Pinelli, P.; Agati, G.; Saracini, E.; Traversi, M.L.; Massai, R. Morpho-anatomical, physiological and biochemical adjustments in response to root zone salinity stress and high solar radiation in two Mediterranean evergreen shrubs, Myrtus communis and Pistacia lentiscus. New Phytol. 2006, 170, 779-794. [CrossRef] [PubMed]

41. Winkel-Shirley, B. Biosynthesis of flavonoids and effects of stress. Curr. Opin. Plant Biol. 2002, 5, $218-223$. [CrossRef]

42. Taylor, L.P.; Grotewold, E. Flavonoids as developmental regulators. Curr. Opin. Plant Biol. 2005, 8, $317-323$. [CrossRef] [PubMed]

43. Dubos, C.; Stracke, R.; Grotewold, E.; Weisshaar, B.; Martin, C.; Lepiniec, L. MYB transcription factors in Arabidopsis. Trends Plant Sci. 2010, 15, 573-581. [CrossRef] [PubMed]

44. Ferreyra, M.L.F.; Rius, S.; Emiliani, J.; Pourcel, L.; Feller, A.; Morohashi, K.; Casati, P.; Grotewold, E. Cloning and characterization of a UV-B-inducible maize flavonol synthase. Plant J. 2010, 62, 77-91. [CrossRef] [PubMed]

45. Heine, G.F.; Hernandez, J.M.; Grotewold, E. Two cysteines in plant R2R3 MYB domains participate in REDOX-dependent DNA binding. J. Biol. Chem. 2004, 279, 37878-37885. [CrossRef] [PubMed]

46. Ben Taarit, M.; Msaada, K.; Hosni, K.; Marzouk, B. Fatty acids, phenolic changes and antioxidant activity of clary sage (Salvia sclarea L.) rosette leaves grown under saline conditions. Ind. Crop. Prod. 2012, 38, 58-63. [CrossRef]

47. Huang, Y.C.; Chang, Y.H.; Shao, Y.Y. Effects of genotype and treatment on the antioxidant activity of sweet potato in Taiwan. Food Chem. 2006, 98, 529-538. [CrossRef]

48. Hichem, H.; Mounir, D.; Naceur, E. Differential responses of two maize (Zea mays L.) varieties to salt stress: Changes on polyphenols composition of foliage and oxidative damages. Ind. Crop. Prod. 2009, 30, 144-151. [CrossRef]

49. Wong, C.C.; Li, H.B.; Cheng, K.W.; Chen, F. A systematic survey of antioxidant activity of 30 Chinese medicinal plants using the ferric reducing antioxidant power assay. Food Chem. 2006, 97, 705-711. [CrossRef]

50. Ascensão, L.; Marques, N.; Pais, M.S. Glandular trichomes on vegetative and reproductive organs of Leonotis leonurus (Lamiaceae). Ann. Bot. 1995, 75, 619-626. [CrossRef]

51. Siebert, D.J. Localization of Salvinorin A and related compounds in glandular trichomes of the psychoactive sage, Salvia divinorum. Ann. Bot. 2004, 93, 763-771. [CrossRef] [PubMed]

52. Karraybouraoui, N.; Rabhi, M.; Neffati, M.; Baldan, B.; Ranieri, A.; Marzouk, B.; Lachaâl, M.; Smaoui, A. Salt effect on yield and composition of shoot essential oil and trichome morphology and density on leaves of Mentha pulegium. Ind. Crop. Prod. 2009, 30, 338-343. [CrossRef]

53. Rodrigues, L.; Póvoa, O.; Teixeira, G.; Figueiredo, A.C.; Moldão, M.; Monteiro, A. Trichomes micromorphology and essential oil variation at different developmental stages of cultivated and wild growing Mentha pulegium L. populations from Portugal. Ind. Crop. Prod. 2013, 43, 692-700. [CrossRef]

54. Farooqi, A.H.A.; Samgwan, N.S.; Sangwan, R.S. Effect of different photoperiodic regimes on growth, flowering and essential oil in Mentha species. Plant Growth Regul. 1999, 29, 181-187. [CrossRef]

55. Kjær, A.; Grevsen, K.; Jensen, M. Effect of external stress on density and size of glandular trichomes in full-grown Artemisia annua, the source of anti-malarial artemisinin. AoB Plants 2012, 2012, pls018. [CrossRef] [PubMed]

56. Wagner, G.J.; Wang, E.; Shepherd, R.W. New approaches for studying and exploiting an old protuberance, the plant trichome. Ann. Bot. 2004, 93, 3-11. [CrossRef] [PubMed]

57. Rahimi, Y.; Taleei, A.; Ranjbar, M. Changes in the expression of key genes involved in the biosynthesis of menthol and menthofuran in Mentha piperita L. under drought stress. Acta Physiol. Plant 2017, 39, 203. [CrossRef]

58. Mccaskill, D.; Gershenzon, J.; Croteau, R. Morphology and monoterpene biosynthetic capabilities of secretory-cell clusters isolated from glandular trichomes of peppermint (Mentha Piperita L.). Planta 1992, 187, 445-454. [CrossRef] [PubMed]

59. Serratovalenti, G.; Bisio, A.; Cornara, L.; Ciarallo, G. Structural and histochemical investigation of the glandular trichomes of Salvia aurea L. Leaves, and chemical analysis of the essential oil. Ann. Bot. 1997, 79, 329-336. [CrossRef]

60. Hoagland, D.R.; Arnon, D.I. The Water-Culture Method for Growing Plants without Soil; California Agricultural Experiment Station: Berkeley, CA, USA, 1950. 
61. Chrysargyris, A.; Panayiotou, C.; Tzortzakis, N. Nitrogen and phosphorus levels affected plant growth, essential oil composition and antioxidant status of lavender plant (Lavandula angustifolia Mill.). Ind. Crop. Prod. 2016, 83, 577-586. [CrossRef]

62. Kim, D.-O.; Jeong, S.W.; Lee, C.Y. Antioxidant capacity of phenolic phytochemicals from various cultivars of plums. Food Chem. 2003, 81, 321-326. [CrossRef]

63. Siddhuraju, P.; Becker, K. Antioxidant properties of various solvent extracts of total phenolic constituents from three different agroclimatic origins of drumstick tree (Moringa oleifera Lam.) leaves. J. Agric. Food Chem. 2003, 51, 2144-2155. [CrossRef] [PubMed]

64. Cai, Y.; Luo, Q.; Sun, M.; Corke, H. Antioxidant activity and phenolic compounds of 112 traditional Chinese medicinal plants associated with anticancer. Life Sci. 2004, 74, 2157-2184. [CrossRef] [PubMed]

65. Severson, R.F.; Arrendale, R.F.; Chortyk, O.T.; Johnson, A.W.; Jackson, D.M.; Gwynn, G.R.; Chaplin, J.F.; Stephenson, M.G. Quantitation of the major cuticular components from green leaf of different tobacco types. J. Agric. Food Chem. 1984, 32, 566-570. [CrossRef]

66. Asai, T.; Fujimoto, Y. Cyclic fatty acyl glycosides in the glandular trichome exudate of Silene gallica. Phytochemistry 2010, 71, 1410-1417. [CrossRef] [PubMed]

(C) 2018 by the authors. Licensee MDPI, Basel, Switzerland. This article is an open access article distributed under the terms and conditions of the Creative Commons Attribution (CC BY) license (http:/ / creativecommons.org/licenses/by/4.0/). 